\title{
Morphological and physiological variation of Fusarium oxysporum f. sp. ciceri isolates causing wilt disease in chickpea
}

\author{
N. Nath ${ }^{1}$, A. U. Ahmed ${ }^{2}$, F. M. Aminuzzaman ${ }^{3 *}$ \\ ${ }^{1}$ Scientific Officer, RSRC, Bangladesh Agricultural Research Institute, Gazipur-1701, Bangladesh \\ ${ }^{2}$ Principal Scientific Officer, Plant Pathology Division, Bangladesh Agricultural Research Institute, Gazipur-1701, \\ Bangladesh \\ ${ }^{3}$ Professor, Department of Plant Pathology, Faculty of Agriculture, Sher-e-Bangla Agricultural University, Sher-e-Bangla \\ Nagar, Dhaka-1207, Bangladesh
}

\begin{abstract}
Nine isolates of Fusarium oxysporum f. sp. ciceri infecting chickpea were collected from major chickpea growing areas of Bangladesh and their cultural, morphological, physiological and pathogenic characteristics were described. The isolates varied significantly in their cultural, morphological and physiological traits, i.e. colony color, shape, margin and texture; mycelial radial growth and spore production. Laboratory studies were conducted to study the effect of different culture media, $p H$ and temperature levels on mycelial growth and sporulation of Fusarium oxysporum f. sp. ciceri. Mycelial radial growth and sporulation of $F$. oxysporum was maximum for all the isolates at $25^{\circ} \mathrm{C}$ after seven days of inoculation, which was reduced drastically below $15^{\circ} \mathrm{C}$ and above $35^{\circ} \mathrm{C}$. No growth and sporulation was observed at $5^{\circ} \mathrm{C}$ temperature for all the isolates. The most suitable $\mathrm{pH}$ level for growth and sporulation of the fungus was at $\mathrm{pH}$ 6.0. The fungus grew well on oat meal agar medium among seven culture media tested. No sporulation was observed on WA medium. The highest number of macro spores $\left(3.27 \times 10^{5} \mathrm{ml}^{-1}\right)$ and micro spores (4.06 $\times 10^{5} \mathrm{ml}^{-1}$ ) were produced on PDA. Among the nine tested isolates, only one isolate (FOC-1) found to be highly virulent $(H V)$ type on reaction on chickpea variety BARI Chola -1 .
\end{abstract}

Keywords- Fusarium oxysporum, variation, morphology, physiology, pathogenicity.

\section{INTRODUCTION}

Chickpea (Cicer arietinum $\mathrm{L}$.) is the third most important grain legume crop in the world and first in the Mediterranean basin and South Asia (Saxena, 1990). Chickpea is a cool season food legume crop grown on 10 million ha in 45 countries in the world and producing $93,13,043$ tones of grain in the world (FAO, 2008). Chickpea is considered as one of the most important legume crops in Bangladesh. Despite of the large area under chickpea cultivation in the world, the total production and productivity are quite low in most of the chickpea growing areas (Pande et al., 2006). The climate and agro-ecological conditions of South Asian countries including Bangladesh favors the rapid growth and development of various plant pathogens (Ahmed, 1996). So, vulnerability of chickpea plant to a number of fungal pathogens from seedling stage to maturity is the primitive cause of low yield. Although a number of biotic and abiotic factors contribute for low chickpea production but endemic occurrence of wilt disease caused by Fusarium oxysporum f. sp. ciceri is of significant importance. Chickpea is reported to be affected by more than 52 pathogens (Nene et al., 1984). Among these, wilt caused by Fusarium oxysporum f. sp. ciceri is a wide spread soil borne diseases, and is reported from many parts of India with intensity ranging from 10 to 100 percent (Singh et al., 1986). Fusarium wilt of chickpea caused by Fusarium oxysporum f. sp. ciceri is an important disease in many chickpea growing areas. This fungus is able to survive in the soil for long period of time by forming resting spores, thick walled reproductive structures. The wilt pathogen is soil-borne and survives through chlamydospores in seed and dead plant debris in soil (Haware et al., 1978). Since, the fungus can survive in the soil for several years; it is not possible to control the disease through normal crop rotations. Although a number of chickpea lines have been reported as resistant to wilt from different countries of the world (Nene et al., 1981), but their success has been highly localized due to location-specific races of the pathogen (Singh and Reddy, 1991). It is important to know which isolate to use in the screening process, how the resistance is expressed and inherited. In view of the above facts, the present research work was aimed to carry out comprehensive investigation on the cultural, morphological, physiological and pathogenic variation of Fusarium oxysporum f. sp. ciceri. 


\section{MATERIALS AND METHODS}

Isolation and identification of the pathogen

Wilt infected plant samples were collected from nine locations covering four chickpea growing districts of Bangladesh. The pathogens that causes wilt disease in chickpea were isolated using tissue culture techniques. The infected chickpea roots were washed and placed into petriplates containing PDA media and incubated at $25{ }^{\circ} \mathrm{C}$ under near ultraviolet (NUV) light following ISTA rules (ISTA, 1996). Seven days after incubation, the fungal culture were studied under stereoscopic (Model: Olympus, SZ 61, Japan) and compound microscope (Model: Olympus, CX 21 FSI, Tokyo, Japan) for identification of the desired pathogens. Then the pathogen purified by single spore culture technique, preserved in PDA slants at $4{ }^{\circ} \mathrm{C}$ for further study.

\section{Morphological variability}

Nine isolates of Fusarium oxysporum $\mathrm{f}$. sp. ciceri isolates were observed on PDA medium after 7 days of inoculation on the basis of colony color, shape, texture, margin, conidial color, size, shape and color of conidiophores.

Effect of culture media on radial mycelial growth of Fusarium oxysporum f. sp. ciceri

Seven culture media viz. potato dextrose agar (PDA) medium (Slice potato-200 g, dextrose-20 g, agar-20 g and distilled water- $1000 \mathrm{ml}$ ), Czapek'sdox agar (CDA) medium (Sucrose - $30 \mathrm{~g}$, sodium nitrate $-2 \mathrm{~g}$, dipotassium phosphate $-1 \mathrm{~g}$, magnesium sulphate $-0.5 \mathrm{~g}$, potas sium chloride $-0.5 \mathrm{~g}$, ferrous sulphate $-0.01 \mathrm{~g}$, agar - $15 \mathrm{~g}$ and distilled water - $1000 \mathrm{ml}$ ), malt extract dextrose agar (MDA) medium (Malt extract - $20 \mathrm{~g}$, peptone $-2 \mathrm{~g}$, dextrose $-20 \mathrm{~g}$, agar $-20 \mathrm{~g}$, and distilled water - $1000 \mathrm{ml}$ ), corn meal agar (CMA) medium (Corn meal infusion form-50 g, agar-15 $\mathrm{g}$ and distilled water$1000 \mathrm{ml}$ ), oat meal agar (OMA) medium (Oat meal - 60 $\mathrm{g}$, agar $-12.5 \mathrm{~g}$ and distilled water $-1000 \mathrm{ml}), \mathrm{V}_{8}$ juice agar $\left(\mathrm{V}_{8} \mathrm{JA}\right)$ medium $\left[\mathrm{V}_{8}\right.$ juice $(100 \mathrm{ml})-8.3 \mathrm{~g}$, Lasparagine $-10 \mathrm{~g}$, yeast extract $-2 \mathrm{~g}$, calcium carbonate $-2 \mathrm{~g}$, glucose $-2 \mathrm{~g}$, agar $-20 \mathrm{~g}$ and distilled water -1000 $\mathrm{ml}$ )] and water agar (WA) medium (Agar - $20 \mathrm{~g}$ and distilled water - $1000 \mathrm{ml}$ ) were used to find out the most suitable one for the mycelia growth of the fungus.

\section{Effect of temperature on radial mycelial growth and sporulation of Fusarium oxysporum $f$. sp. ciceri}

The fungus was inoculated in PDA media using seven different levels of temperature viz., 5, 10, 15, 20, 25, 30 and to determine the temperature effect on radial colony growth and sporulation of Fusarium oxysporum f. sp. ciceri.

Effect of pH levels radial mycelial growth of Fusarium oxysporum $f$. $s p$. ceceri

The isolates were inoculated in PDA medium having six $\mathrm{pH}$ levels viz., 4.5, 5.0, 5.5, 6.0, 6.5 and 7.0 in $9 \mathrm{~cm}$ diameter glass petriplates and incubated at $25 \pm 0.5{ }^{\circ} \mathrm{C}$ with alternating 12 hours of light and 12 hours of dark period in an incubator. The different level of $\mathrm{pH}$ were maintained by adding $0.1 \mathrm{~N} \mathrm{NaOH}$ or $0.1 \mathrm{~N} \mathrm{HCl}$.

For all the tests, $16 \mathrm{ml}$ of medium were poured into each Petri plates using media dispenser having three replications. The medium autoclaved at $121{ }^{\circ} \mathrm{C}$ for 30 minutes at 15 PSI and then allowed for solidification in laminar airflow cabinet. Five mm diameter of mycelial disc were cut from the periphery of 7 days old culture of Fusarium oxysporum f. sp. ciceri with the help of a flame sterilized cork borer and then transferred into the centre of the petriplates containing solidified PDA medium. Then the plates were placed in an incubator maintaining required temperature level for temperature study. Data were noted on mycelial radial growth of Fusarium oxysporum f. sp. ciceri after two day of incubation till covering the entire petriplates of any isolates. The number of spores of Fusarium oxysporum $\mathrm{f}$. sp. ciceri on different temperature and $\mathrm{pH}$ levels were counted using haemacytometer after 7 days of incubation. One (1) $\mathrm{ml}$ distilled water was poured in each test-tube and $5 \mathrm{~mm}$ block of Fusarium oxysporum f. sp. ciceri isolates were put into the test-tube. Then the test-tubes were shaken by vortex shaker. After shaking, spores were counted using haemacytometer. The spore counting process was repeated 10 times of each replication.

Pathogenic variability

Plastic pots $(8 \times 10 \mathrm{~cm})$ were used to grow chickpea plants in the pot house of Plant Pathology Division, Bangladesh Agricultural Research Institute (BARI), Gazipur. The pots were filled with $500 \mathrm{gm}$ sterilized soil with well decomposed organic matter. In order to get a huge amount of inocula of Fusarium oxysporum f. sp. ciceri, isolates were sub-cultured on PDA medium and incubated for 10 days. One pertriplate $(90 \mathrm{~mm})$ full of inocula (mycelial mat and spores) were scraped by a plastic scrapper, wrapped with alluminium foil and preserved in the room temperature. Previously prepared inocula were incorporated into the sterilized soil. Five seeds of BARI Chola-1 were sown in each pot having three replications. Prior to sowing seeds were surface sterilized with Clorox ( $0.1 \%$ available chlorine) for 50 seconds and were rinsed by sterile distilled water for three times. The pots were kept in the net house of the Plant Pathology Division, BARI. Wilt incidence were recorded at 30, 45 and 60 
DAI but aggressiveness of the tested isolates were measured considering wilt incidence only at 60 DAI (days after inoculation). Koch's postulates were proved and pathogenic nature of each is olate was established.

\section{RESULTS AND DISCUSSION}

\section{Morphological variability}

Fusarium oxysporum f. sp. ciceri exhibited variations in colony characteristics such as color, shape, margin and texture. Colony colors were purplish white, whitish orange, creamy white, cottony white. Colony shapes were irregular, regular, regular with sector, regular without sector. Colony margins were irregular, entire and wavy. Colony textures were fluffy, flat/velvet (Table 1). In past studies various type of pigmentations (yellow, brown, crimson) in culture has been recorded (Saxena and Singh, 1987). Chauhan (1962) found variation among 22 isolates with respect to their mycelium type, colony colour, toxin production and pathogenicity. Fusarium wilt isolates were highly variable in their colony growth pattern, size of colony and pigmentations. The current findings were well supported by Dubey et al., (2010). In this experiment it was observed that the length of micro conidia varied from 5.00-14.00 $\mu \mathrm{m}$. The breadth of micro conidia was 1.00-4.00 $\mu \mathrm{m}$. Micro conidia was 0-2 septed. The length and breadth of macro conidia ranged from 9.00-26.00 $\mu \mathrm{m}$ and 1.00-5.00 $\mu \mathrm{m}$ respectively. The number of septation of macro conidia ranged from 1-5. F. oxysporum f. sp. ciceri showed variations in the size of micro and macroconidia of 9 isolates with three replications was also studied. The largest size of the micro-conidia was obtained from the isolate Foc-14 $(3.7 \times 4.5,3.1 \times 5.0 \mu \mathrm{m})$ and the smallest size was from isolates FOC-21 $(3.0 \times 3.7$ $\mu \mathrm{m})$. Whereas, the biggest size $7.5 \times 20.10 \mu \mathrm{m}$ of the macro-conidia was obtained from the isolates Foc-25 and the smallest size of $3.5 \times 22.5 \mu \mathrm{m}$ conidia were obtained from isolates Foc-11(Table 1).

Effect of temperature on mycelial radial growth and sporulation

As evident from Fig. 1, the fungus grew at the temperature range of $10-35^{\circ} \mathrm{C}$. Maximum growth was found between $25^{\circ} \mathrm{C}$ and $30{ }^{\circ} \mathrm{C}$ for all the 9 is olates after 7 days of incubation. At $25^{\circ} \mathrm{C}$ maximum colony diameter
$(78.00 \mathrm{~mm})$ was obtained in isolate FOC-2 followed by FOC-9 $(76.67 \mathrm{~mm})$. The lowest colony growth $(9.66 \mathrm{~mm})$ was noted at $35{ }^{\circ} \mathrm{C}$ in FOC-2. The present findings agreed with the findings of Farooq et al., (2005). They reported that the growth of the $F$. oxysporum f. sp. ciceri was drastically reduced below $15{ }^{\circ} \mathrm{C}$ and started to decline above $35{ }^{\circ} \mathrm{C}$, as these temperatures did not favor for growth of the fungus. It was observed that at $25^{\circ} \mathrm{C}$ and $30^{\circ} \mathrm{C}$, the fungus attained the maximum growth of 76.8 and $85.4 \mathrm{~mm}$ while at $15^{\circ} \mathrm{C}$, it was $59.3 \mathrm{~mm}$ after seven days of inoculation. No growth was observed at $5{ }^{\circ} \mathrm{C}$. The highest $\left(6.78 \times 10^{5} \mathrm{ml}^{-1}\right)$ sporulation of micro conidia was observed in FOC- 3 at $25{ }^{\circ} \mathrm{C}$ followed by FOC-6 (6.00 x $\left.10^{5} \mathrm{ml}^{-1}\right)$; FOC-1 $\left(5.13 \times 10^{5} \mathrm{ml}^{-1}\right)$ and FOC-7 $\left(3.70 \times 10^{5}\right.$ $\mathrm{ml}^{-1}$ ) after seven days of incubation period. The minimum $\left(3.30 \times 10^{3} \mathrm{ml}^{-1}\right)$ sporulation was observed in FOC-4 at 15 ${ }^{\circ} \mathrm{C}$. Spore production was not observed in isolates at $5^{\circ} \mathrm{C}$ in FOC-1 and FOC- 2 at $10^{\circ} \mathrm{C}$, in FOC-9 at $15^{\circ} \mathrm{C}$ and in FOC-4, FOC-5, FOC-7 at $35{ }^{\circ} \mathrm{C}$ (Table 2). The maximum (3.43 x $\left.10^{6} \mathrm{ml}^{-1}\right)$ sporulation of macro conidia was observed in FOC-1 followed by FOC-6 (6.66 x $\left.10^{5} \mathrm{ml}^{-1}\right)$ and FOC-9 $\left(5.58 \times 10^{5} \mathrm{ml}^{-1}\right)$ at $25^{\circ} \mathrm{C}$ after seven days of incubation period. The minimum $\left(1.66 \mathrm{x} 10^{3} \mathrm{ml}^{-1}\right)$ sporulation was observed in FOC-5 and FOC-8 at $15^{\circ} \mathrm{C}$ and FOC-2 $\left(1.66 \times 10^{3} \mathrm{ml}^{-1}\right)$ at $35^{\circ} \mathrm{C}$. All the nine isolates failed to produce any spore at $5{ }^{\circ} \mathrm{C}$ temperature (Table 3 ). Abundant sporulation of this fungus was found after seven days of incubation at $27 \pm 2{ }^{\circ} \mathrm{C}$ on potato dextrose agar medium (Barhate, 2006). This observation supports the result obtained from this study. Khilare and Rafi Ahmed (2012) stated the highest growth of pathogen was recorded at $30{ }^{\circ} \mathrm{C}$ with higher sporulation 27.90 conidia $\mu \mathrm{l}^{-1}$ and after seven days of incubation, which was reduced drastically below $15{ }^{\circ} \mathrm{C}$ and above $35{ }^{\circ} \mathrm{C}$. Chauhan (1963) and Desai et al., (1994) found that $25^{\circ} \mathrm{C}$ is the optimum temperature for growth of Fusarium wilt. Similarly, Sharma et al., (2005) verify that a temperature around $25{ }^{\circ} \mathrm{C}$ is optimum for disease development. While, Mina and Dubey (2010) observed maximum colony diameter $(85 \mathrm{~mm})$ at $28{ }^{\circ} \mathrm{C}$. From this experiment, it appeared that $25{ }^{\circ} \mathrm{C}$ temperature is suitable for mycelial radial growth and spore production of Fusarium oxysporum f. sp. ciceri.

Table.1: Morphological variability in the isolates of Fusarium oxysporumf. sp. ciceri

\begin{tabular}{|l|l|l|l|l|l|l|l|l|l|l|}
\hline \multirow{2}{*}{ Isolates } & \multicolumn{9}{|l|}{ Cultural characters } & \multicolumn{3}{l|}{ Dimension and septation } \\
\cline { 2 - 12 } & Color & Shape & Margin & Texture & $\begin{array}{l}\text { Mength conidia } \\
(\mu \mathrm{m})\end{array}$ & $\begin{array}{l}\text { Breadth } \\
(\mu \mathrm{m})\end{array}$ & Septation & $\begin{array}{l}\text { Length } \\
(\mu \mathrm{m})\end{array}$ & $\begin{array}{l}\text { Breadth } \\
(\mu \mathrm{m})\end{array}$ & Septation \\
\hline FOC 1 & $\begin{array}{l}\text { Purplish } \\
\text { white }\end{array}$ & Irregular & Irregular & Fluffy & $6-14$ & $2-4$ & $0-1$ & $12-25$ & $1.5-5$ & $3-5$ \\
\hline
\end{tabular}




\begin{tabular}{|c|c|c|c|c|c|c|c|c|c|c|}
\hline FOC 2 & $\begin{array}{l}\text { Whitish } \\
\text { orange }\end{array}$ & Regular & Entire & Fluffy & $6-14$ & $1.5-3$ & $0-2$ & $11-25$ & $2-4$ & $2-5$ \\
\hline FOC 3 & $\begin{array}{l}\text { Creamy } \\
\text { white }\end{array}$ & Regular & Entire & Flat/Velvet & $5-10$ & $1-3$ & $0-1$ & $9-15$ & $2-3$ & $1-4$ \\
\hline FOC 4 & $\begin{array}{l}\text { Creamy } \\
\text { white }\end{array}$ & $\begin{array}{l}\text { Regular } \\
\text { without } \\
\text { sector }\end{array}$ & Wavy & Flat/Velvet & $5-9$ & $1.5-3$ & 0 & $10-18$ & $2-3$ & $1-4$ \\
\hline FOC 5 & $\begin{array}{l}\text { Cottony } \\
\text { white }\end{array}$ & $\begin{array}{l}\text { Regular } \\
\text { without } \\
\text { sector }\end{array}$ & $\begin{array}{l}\text { Wavy, } \\
\text { entire }\end{array}$ & Flat/Velvet & $6-8$ & $1.5-3$ & $0-1$ & $11-25$ & $2-4$ & $1-4$ \\
\hline FOC 6 & $\begin{array}{l}\text { Creamy } \\
\text { white }\end{array}$ & Regular & Wavy & Flat/Velvet & $6-11$ & $1.5-3$ & $0-1$ & $12-25$ & $1-4$ & $2-5$ \\
\hline FOC 7 & $\begin{array}{l}\text { Whitish } \\
\text { orange }\end{array}$ & Irregular & Irregular & Fluffy & $5-12$ & $1-3$ & $0-1$ & $15-26$ & $2-5$ & $2-5$ \\
\hline FOC 8 & $\begin{array}{l}\text { Cottony } \\
\text { white }\end{array}$ & $\begin{array}{l}\text { Regular } \\
\text { with } \\
\text { sector }\end{array}$ & $\begin{array}{l}\text { Wavy, } \\
\text { entire }\end{array}$ & Fluffy & $7-11$ & $1-3$ & $0-1$ & $12-25$ & $2-4$ & $2-5$ \\
\hline FOC 9 & $\begin{array}{l}\text { Cottony } \\
\text { white }\end{array}$ & Irregular & Irregular & Fluffy & $5-10$ & $1-3$ & $0-1$ & $11-16$ & $2-3$ & $1-3$ \\
\hline
\end{tabular}
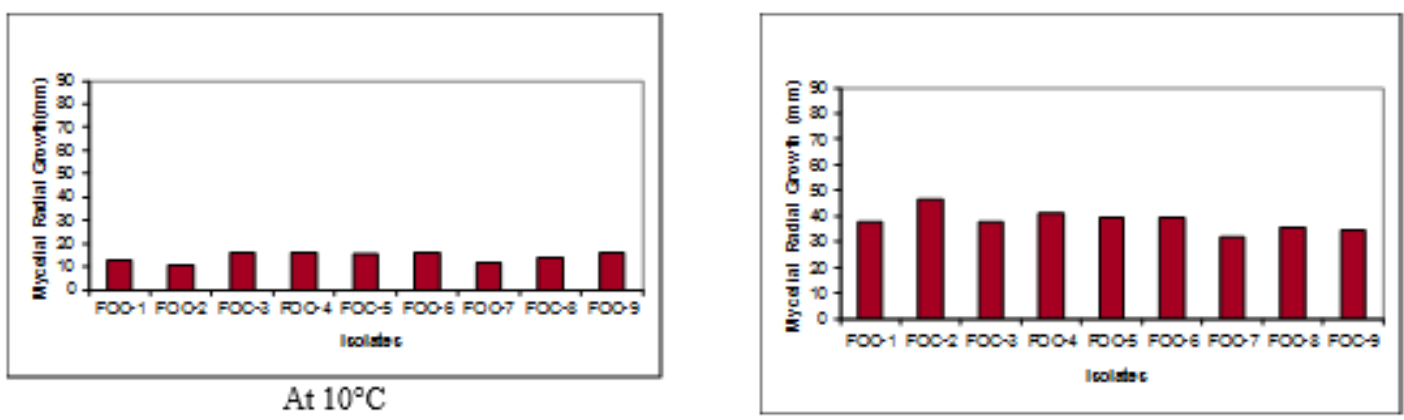

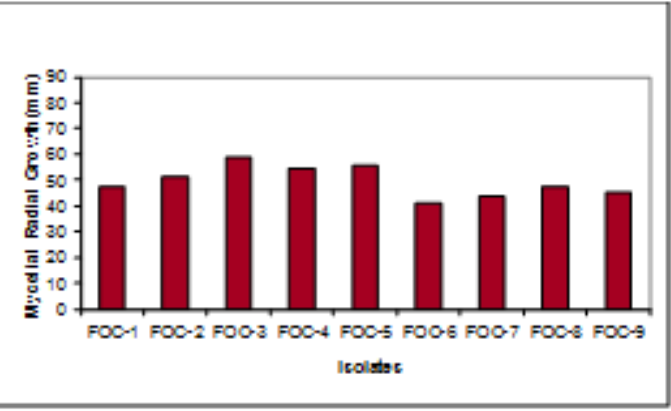

At $20^{\circ} \mathrm{C}$

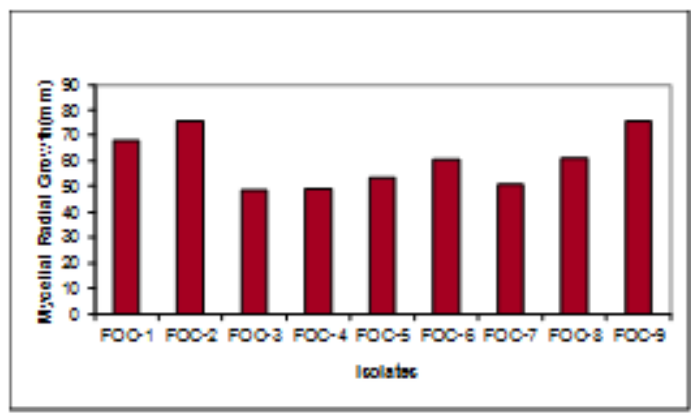

At $30^{\circ} \mathrm{C}$

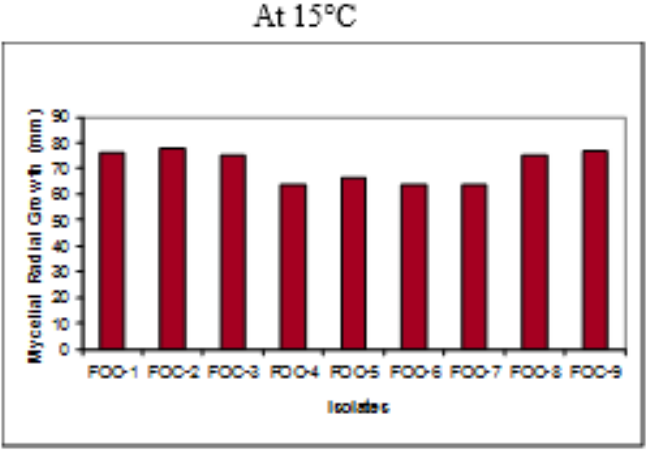

At $25^{\circ} \mathrm{C}$

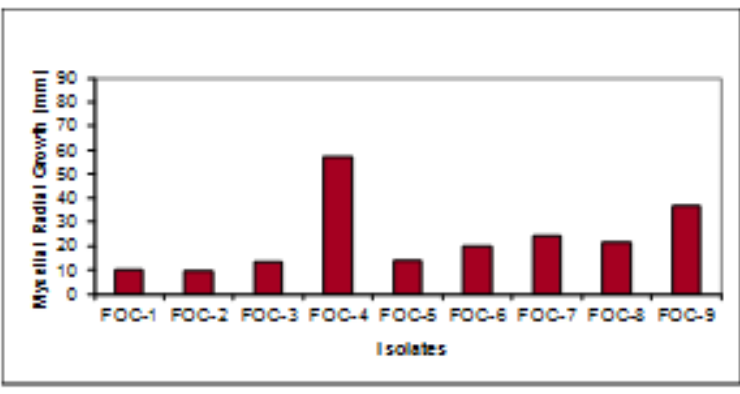

At $35^{\circ} \mathrm{C}$

Fig.1: Radial mycelial growth of Fusarium oxysporumf. sp. ciceri at different temperature $\left({ }^{\circ} \mathrm{C}\right)$ levels. 
Table.2: Effect of temperature on production of micro conidia of nine Fusarium oxysporum $f$. sp. ciceri isolates

\begin{tabular}{c|c|c|c|c|c|c|c}
\hline \multirow{2}{*}{ Isolates } & \multicolumn{7}{|c}{ Production of micro conidia $\left(\mathbf{m l}^{-\mathbf{1}}\right)$ at different } \\
& $\mathbf{5}$ & $\mathbf{1 0}$ & $\mathbf{1 5}$ & $\mathbf{2 0}$ & $\mathbf{2 5}$ & $\mathbf{3 0}$ & $\mathbf{3 5}$ \\
\hline FOC-1 & $*$ & $*$ & $3.33 \times 10^{4}$ & $6.38 \times 10^{4}$ & $5.13 \times 10^{5}$ & $1.12 \times 10^{5}$ & $3.38 \times 10^{4}$ \\
FOC-2 & $*$ & $*$ & $2.61 \times 10^{4}$ & $7.33 \times 10^{4}$ & $1.66 \times 10^{5}$ & $9.38 \times 10^{4}$ & $5.61 \times 10^{4}$ \\
FOC-3 & $*$ & $* *$ & $6.27 \times 10^{3}$ & $8.25 \times 10^{3}$ & $6.78 \times 10^{5}$ & $3.86 \times 10^{4}$ & $2.71 \times 10^{4}$ \\
FOC-4 & $*$ & $* *$ & $3.30 \times 10^{3}$ & $1.00 \times 10^{4}$ & $1.25 \times 10^{5}$ & $1.83 \times 10^{4}$ & $*$ \\
FOC-5 & $*$ & $* *$ & $4.00 \times 10^{4}$ & $1.36 \times 10^{5}$ & $3.63 \times 10^{5}$ & $2.98 \times 10^{5}$ & $*$ \\
FOC-6 & $*$ & $* *$ & $3.66 \times 10^{4}$ & $1.01 \times 10^{5}$ & $6.00 \times 10^{5}$ & $3.60 \times 10^{5}$ & $1.83 \times 10^{5}$ \\
FOC-7 & $*$ & $* *$ & $5.33 \times 10^{4}$ & $2.85 \times 10^{5}$ & $3.70 \times 10^{5}$ & $1.38 \times 10^{5}$ & $*$ \\
FOC-8 & $*$ & $* *$ & $4.16 \times 10^{4}$ & $7.66 \times 10^{4}$ & $2.61 \times 10^{5}$ & $8.50 \times 10^{4}$ & $3.83 \times 10^{4}$ \\
FOC-9 & $*$ & $* *$ & $*$ & $1.16 \times 10^{4}$ & $9.66 \times 10^{4}$ & $5.16 \times 10^{4}$ & $8.33 \times 10^{3}$ \\
\hline
\end{tabular}

* No sporulation

$* *$ Very few sporulation

Table.3: Effect of temperature on production of macro conidia of nine Fusarium oxysporum f. sp. ciceri isolates

\begin{tabular}{c|c|c|c|c|c|c|c}
\hline \multirow{2}{*}{ Is olates } & \multicolumn{7}{|c}{ Production of macro conidia $\left(\mathbf{m l}^{\mathbf{- 1}}\right)$ at different temperature levels $\left({ }^{\circ} \mathbf{C}\right)$} \\
\cline { 2 - 7 } & $\mathbf{5}$ & $\mathbf{1 0}$ & $\mathbf{1 5}$ & $\mathbf{2 0}$ & $\mathbf{2 5}$ & $\mathbf{3 0}$ & $\mathbf{3 5}$ \\
\hline FOC-1 & $*$ & $* *$ & $2.11 \times 10^{4}$ & $5.22 \times 10^{4}$ & $3.43 \times 10^{6}$ & $1.64 \times 10^{5}$ & $1.33 \times 10^{4}$ \\
FOC-2 & $*$ & $* *$ & $2.44 \times 10^{4}$ & $7.33 \times 10^{4}$ & $1.56 \times 10^{5}$ & $1.03 \times 10^{5}$ & $1.66 \times 10^{3}$ \\
FOC-3 & $*$ & $*$ & $6.44 \times 10^{3}$ & $1.06 \times 10^{4}$ & $4.33 \times 10^{4}$ & $1.97 \times 10^{4}$ & $*$ \\
FOC-4 & $*$ & $* *$ & $2.50 \times 10^{4}$ & $8.66 \times 10^{4}$ & $1.33 \times 10^{5}$ & $2.66 \times 10^{4}$ & $1.66 \times 10^{4}$ \\
FOC-5 & $*$ & $*$ & $1.66 \times 10^{3}$ & $3.33 \times 10^{3}$ & $2.00 \times 10^{4}$ & $1.00 \times 10^{4}$ & $*$ \\
FOC-6 & $*$ & $*$ & $*$ & $6.66 \times 10^{3}$ & $6.66 \times 10^{5}$ & $1.66 \times 10^{3}$ & $*$ \\
FOC-7 & $*$ & $* *$ & $*$ & $1.00 \times 10^{4}$ & $2.70 \times 10^{5}$ & $3.33 \times 10^{3}$ & $3.33 \times 10^{3}$ \\
FOC-8 & $*$ & $* *$ & $1.66 \times 10^{3}$ & $3.33 \times 10^{3}$ & $3.83 \times 10^{4}$ & $*$ & $*$ \\
FOC-9 & $*$ & $*$ & $5.33 \times 10^{4}$ & $1.73 \times 10^{5}$ & $5.58 \times 10^{5}$ & $2.61 \times 10^{5}$ & $6.33 \times 10^{4}$ \\
\hline
\end{tabular}

* No sporulation

** Very few sporulation

Effect of pH on mycelial radial growth and sporulation The results of this experiment indicated that luxuriant radial growth exhibited in all of the isolates at $\mathrm{pH} 6.0$ and pH 6.5 (Fig. 2). The highest colony diameter was noted for the isolate FOC-2 at $\mathrm{pH} 6.0(87.83 \mathrm{~mm})$ followed by FOC-1 $(86.17 \mathrm{~mm})$ at $\mathrm{pH} 6.0$ and FOC-8 $(84.50 \mathrm{~mm})$ at $\mathrm{pH}$ 6.0. The lowest mycelial radial growth was recorded in isolate FOC-1 $(24.83 \mathrm{~mm})$ at $\mathrm{pH}$ 4.5. Farooq et al., (2005) reported that $F$. oxysporum f. sp. ciceri can grow well at $\mathrm{pH} 7$ where the radial growth was $80 \mathrm{~mm}$ after seven days of inoculation. They also observed that the growth of the fungus decreased by increasing or decreasing the $\mathrm{pH}$ level from the neutral level. Imran Khan et al., (2011) showed optimum $\mathrm{pH}$ for growth of $F$. oxysporum f. sp. ciceri ranged from $\mathrm{pH} 6.5$ to 7.0. $F$. oxysporum f. sp. ciceri has ability to tolerate $\mathrm{pH}$ 5.0-6.5, at a wide range (Shaikh, 1974). Maximum $\left(3.03 \times 10^{5} \mathrm{ml}^{-}\right.$ 1) micro conidia was produced by FOC-7 at $\mathrm{pH} 6.0$ followed by FOC-5 (1.86 x $\left.10^{5} \mathrm{ml}^{-1}\right)$ and minimum sporulation was observed on FOC-3 $\left(8.87 \times 10^{3} \mathrm{ml}^{-1}\right)$ at pH 4.5 after seven days of incubation period (Table 4). Maximum (7.06 x $10^{5} \mathrm{ml}^{-1}$ ) macro conidia were produced by FOC-9 at $\mathrm{pH} 6.0$ and minimum sporulation was observed on FOC-6 $\left(1.66 \times 10^{3} \mathrm{ml}^{-1}\right)$ at $\mathrm{pH} 4.5$. No macro conidia was produced by FOC-9 at 4.5 ; FOC-7 and FOC8 at $\mathrm{pH} 6.5$ and FOC-4, FOC-5 and FOC-8 at pH 7.0 (Table 5). Khilare and Rafi Ahmed (2012) reported that the highest sporulation of $F$. oxysporum f. sp. ciceri was 24.70 conidia $\mu \mathrm{l}^{-1}$ at $\mathrm{pH}$ 6.0. T. Swati and P. Rajan (2014) found that the Maximum sporulation of the macro conidia and micro conidia was observed at $\mathrm{pH} 6.5$ (5.06 and 122.4 spore $/ 100 \mathrm{~mL}$ of medium respectively) and minimum sporulation occurred in $\mathrm{pH} 2.0$ ( 0.47 and 2.42 spore/100 $\mathrm{mL}$ of medium respectively). Chaudhary (1971) and Prasad et al. (1992) reported $6.0 \mathrm{pH}$ level as the best for the growth and sporulation of Fusarium moniliforme $v$ subglutinanse. 


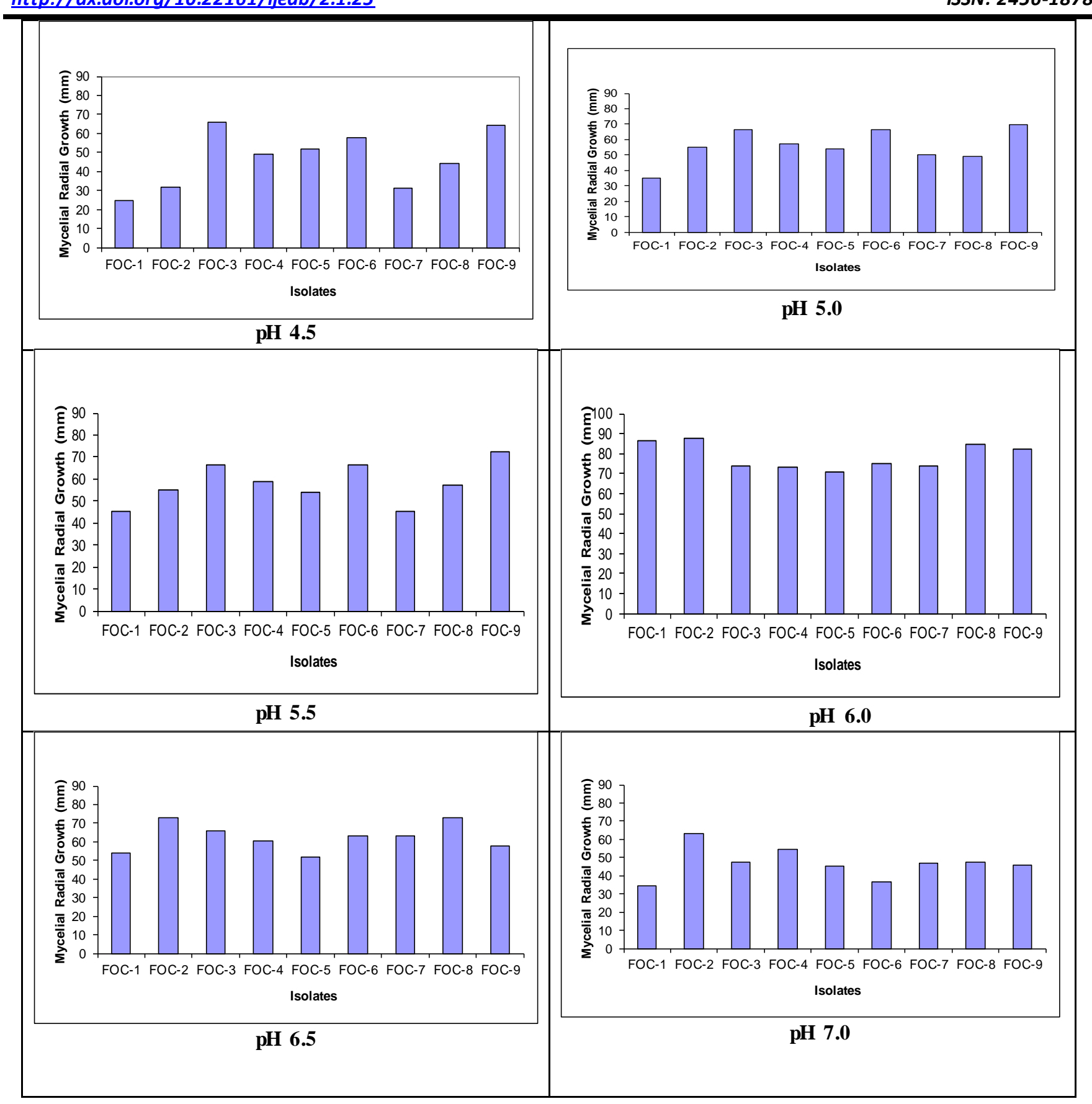

Fig.2: Effect of pH on mycelial radial growth of Fusarium oxysporumf. sp. ciceri isolates.

Table.4: Effect of pH on production of micro conidia of Fusarium oxysporumf. sp. ciceri isolates

\begin{tabular}{|c|c|c|c|c|c|c|}
\hline \multirow[t]{2}{*}{ Is olates } & \multicolumn{6}{|c|}{ Production of micro conidia $\left(\mathrm{ml}^{-1}\right)$ at different $\mathrm{pH}$ levels } \\
\hline & 4.5 & 5.0 & 5.5 & 6.0 & 6.5 & 7.0 \\
\hline FOC-1 & $5.61 \times 10^{4}$ & $5.77 \times 10^{4}$ & $6.72 \times 10^{4}$ & $8.00 \times 10^{4}$ & $6.72 \times 10^{4}$ & $5.27 \times 10^{4}$ \\
\hline FOC-2 & $3.94 \times 10^{4}$ & $4.72 \times 10^{4}$ & $7.50 \times 10^{4}$ & $7.50 \times 10^{4}$ & $5.88 \times 10^{4}$ & $5.77 \times 10^{4}$ \\
\hline FOC-3 & $8.87 \times 10^{3}$ & $1.06 \times 10^{4}$ & $1.33 \times 10^{4}$ & $8.03 \times 10^{4}$ & $1.61 \times 10^{4}$ & $1.31 \times 10^{4}$ \\
\hline FOC-4 & $4.50 \times 10^{4}$ & $5.00 \times 10^{4}$ & $6.00 \times 10^{4}$ & $1.51 \times 10^{5}$ & $9.50 \times 10^{4}$ & $5.00 \times 10^{4}$ \\
\hline FOC-5 & $3.66 \times 10^{4}$ & $3.83 \times 10^{4}$ & $5.83 \times 10^{4}$ & $1.86 \times 10^{5}$ & $6.16 \times 10^{4}$ & $6.00 \times 10^{4}$ \\
\hline FOC-6 & $2.50 \times 10^{4}$ & $4.00 \times 10^{4}$ & $7.16 \times 10^{4}$ & $1.56 \times 10^{5}$ & $8.83 \times 10^{4}$ & $7.33 \times \quad 10^{4}$ \\
\hline FOC-7 & $6.16 \times 10^{4}$ & $7.33 \times 10^{4}$ & $1.03 \times 10^{5}$ & $3.03 \times 10^{5}$ & $1.61 \times 10^{5}$ & $1.58 \times 10^{5}$ \\
\hline
\end{tabular}




\begin{tabular}{lllllll} 
FOC-8 & $1.16 \times 10^{4}$ & $3.50 \times 10^{4}$ & $3.66 \times 10^{4}$ & $7.33 \times 10^{4}$ & $6.66 \times 10^{4}$ & $6.83 \times 10^{4}$ \\
FOC-9 & $1.16 \times 10^{4}$ & $2.33 \times 10^{4}$ & $3.00 \times 10^{4}$ & $1.01 \times 10^{5}$ & $8.83 \times 10^{4}$ & $6.50 \times 10^{4}$ \\
\hline
\end{tabular}

Table.5: Effect of pH on production of macro conidia of 9 Fusarium oxysporumf. sp. ciceri isolates

\begin{tabular}{c|c|c|c|c|c|c}
\hline \multirow{2}{*}{ Is olates } & \multicolumn{7}{c}{ Production of macro conidia $\left(\mathbf{m l}^{\mathbf{- 1}}\right)$ at different $\mathbf{p H}$ levels } \\
\cline { 2 - 7 } & $\mathbf{4 . 5}$ & $\mathbf{5 . 0}$ & $\mathbf{5 . 5}$ & $\mathbf{6 . 0}$ & $\mathbf{6 . 5}$ & $\mathbf{7 . 0}$ \\
\hline FOC-1 & $2.50 \times 10^{4}$ & $5.72 \times 10^{4}$ & $1.72 \times 10^{5}$ & $3.90 \times 10^{5}$ & $1.38 \times 10^{4}$ & $1.00 \times 10^{4}$ \\
FOC-2 & $2.00 \times 10^{4}$ & $5.05 \times 10^{4}$ & $8.61 \times 10^{4}$ & $4.76 \times 10^{5}$ & $8.33 \times 10^{4}$ & $1.33 \times 10^{4}$ \\
FOC-3 & $1.00 \times 10^{4}$ & $1.35 \times 10^{4}$ & $5.47 \times 10^{4}$ & $1.50 \times 10^{5}$ & $2.30 \times 10^{4}$ & $1.16 \times 10^{4}$ \\
FOC-4 & $5.00 \times 10^{3}$ & $6.66 \times 10^{3}$ & $3.25 \times 10^{5}$ & $3.80 \times 10^{5}$ & $6.66 \times 10^{3}$ & $*$ \\
FOC-5 & $3.50 \times 10^{4}$ & $9.33 \times 10^{4}$ & $6.66 \times 10^{3}$ & $2.30 \times 10^{5}$ & $1.66 \times 10^{3}$ & $*$ \\
FOC-6 & $1.66 \times 10^{3}$ & $1.66 \times 10^{3}$ & $5.00 \times 10^{3}$ & $7.00 \times 10^{4}$ & $1.00 \times 10^{4}$ & $8.33 \times 10^{3}$ \\
FOC-7 & $3.33 \times 10^{3}$ & $8.33 \times 10^{3}$ & $9.83 \times 10^{4}$ & $1.65 \times 10^{5}$ & $*$ & $2.00 \times 10^{4}$ \\
FOC-8 & $1.66 \times 10^{3}$ & $3.33 \times 10^{3}$ & $5.66 \times 10^{4}$ & $8.66 \times 10^{4}$ & $*$ & $*$ \\
FOC-9 & $*$ & $1.42 \times 10^{3}$ & $5.21 \times 10^{5}$ & $7.06 \times 10^{5}$ & $6.00 \times 10^{4}$ & $3.33 \times 10^{3}$ \\
\hline
\end{tabular}

* No sporulation

\section{Effect of culture media on mycelial radial growth and sporulation}

The results of the experiment revealed that the most effective medium supporting the growth of the fungus was oat meal agar medium (OMA) followed by Czapek's dox agar (CDA) medium which gave $90.00 \mathrm{~mm}$ and 84.50 $\mathrm{mm}$ mycelium colony growth of $F$. oxysporum f. sp. ciceri after an incubation of seven days respectively (Fig. 3 ). The results of the present study are in agreement with those achieved by Farooq et al., (2005). He mentioned that Minimum fungal growth was observed on PDA and the Czapeck's dox agar and CSMA media were the best for the radial growth of $F$. oxysporum as this fungus gave maximum growth of 85 and $80 \mathrm{~mm}$, respectively. Maximum (4.06 x $10^{5} \mathrm{ml}^{-1}$ ) micro conidia was produced by FOC-5 at PDA medium and minimum $\left(2.41 \times 10^{3} \mathrm{ml}^{-}\right.$ $\left.{ }^{1}\right)$ sporulation was observed on FOC-3 at CDA medium. No micro conidia were produced by FOC-4 at $\mathrm{V}_{8} \mathrm{JA}$ and all is olates of WA medium (Table 6).

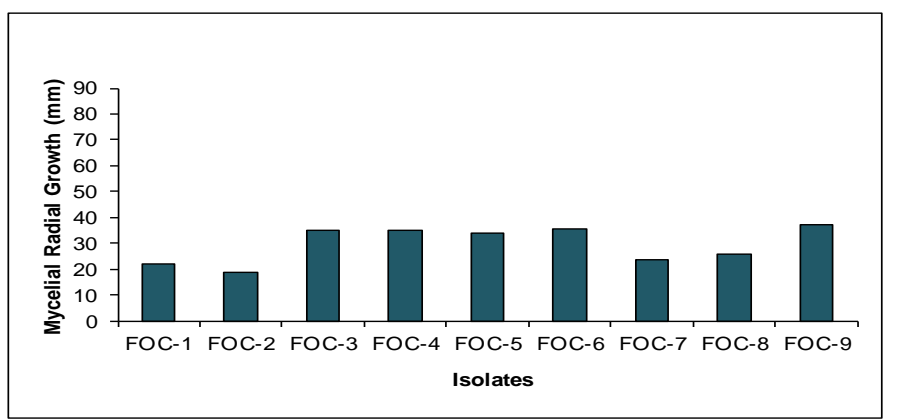

PDA
The highest sporulation of macro conidia was observed on FOC-1 $\left(3.27 \times 10^{5} \mathrm{ml}^{-1}\right)$ at PDA medium and the lowest sporulation was observed on FOC-3 $\left(1.08 \times 10^{3}\right.$ $\left.\mathrm{ml}^{-1}\right)$ at $\mathrm{V}_{8} \mathrm{JA}$ medium. No sporulation was observed on FOC-8 at CDA; FOC-5, FOC-6, FOC-8 at MDA; FOC-6 at OMA and all isolates of WA medium (Table 7). Recently Imran Khan et al., (2011) studied effect of media on $F$. oxysporum f. sp. ciceri and found that PDA is best for the growth of different isolates. Khilare and Rafi Ahmed (2012) found that the fungus grew the best on Czapek's dox agar and PDA media among six culture media were tested. Jamaria (1972) reported maximum growth and sporulation of F. oxysporum $\mathrm{f}$. sp. vanillae on potato dextrose agar, Richard's agar and Czapek's Dox agar. Khare et al., (1975) reported maximum growth of Fusarium oxysporum f. sp. lentis on PDA followed by lentil extract and Richard's Agar.

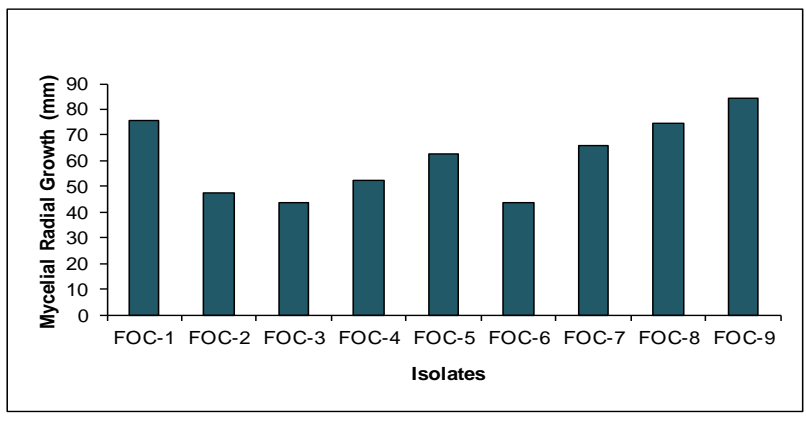

CDA 

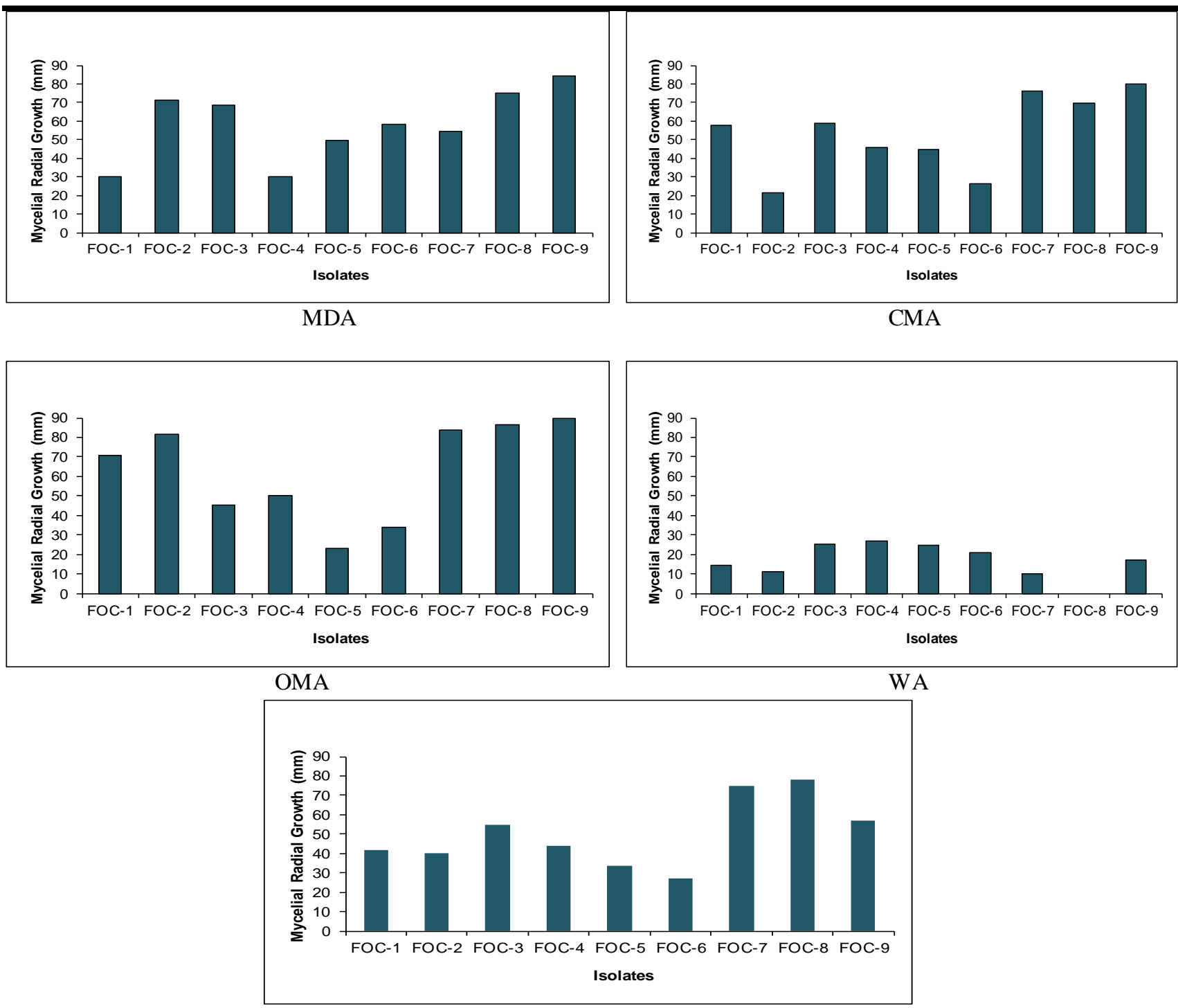

$\mathrm{V}_{8} \mathrm{JA}$

Fig.3: Effect of culture media on mycelial radial growth and sporulation ofnine Fusarium oxysporumf. sp. ciceri isolates.

Table.6: Effect of culture media on production of micro conidia of nine Fusarium oxysporumf. sp. ciceri isolates

\begin{tabular}{c|c|c|c|c|c|c|c}
\hline \multirow{2}{*}{ Is olates } & \multicolumn{7}{c}{ Production of micro conidia $\mathbf{~ m l}^{-1}$ ) on different media } \\
\cline { 2 - 8 } & PDA & CDA & MDA & CMA & OMA & WA & V8 JA \\
\hline FOC-1 & $1.82 \times 10^{5}$ & $1.33 \times 10^{4}$ & $1.27 \times 10^{4}$ & $1.55 \times 10^{4}$ & $2.16 \times 10^{4}$ & $*$ & $7.22 \times 10^{3}$ \\
FOC-2 & $1.13 \times 10^{5}$ & $1.33 \times 10^{4}$ & $1.88 \times 10^{4}$ & $1.00 \times 10^{4}$ & $2.05 \times 10^{4}$ & $*$ & $6.11 \times 10^{3}$ \\
FOC-3 & $3.28 \times 10^{4}$ & $2.41 \times 10^{3}$ & $5.25 \times 10^{3}$ & $4.32 \times 10^{3}$ & $1.11 \times 10^{4}$ & $*$ & $4.32 \times 10^{3}$ \\
FOC-4 & $3.83 \times 10^{4}$ & $2.83 \times 10^{4}$ & $3.33 \times 10^{3}$ & $8.33 \times 10^{3}$ & $1.33 \times 10^{4}$ & $*$ & $*$ \\
FOC-5 & $4.06 \times 10^{5}$ & $1.16 \times 10^{4}$ & $8.33 \times 10^{3}$ & $1.00 \times 10^{4}$ & $2.16 \times 10^{4}$ & $*$ & $1.16 \mathrm{x} 10^{4}$ \\
FOC-6 & $4.66 \times 10^{4}$ & $1.00 \times 10^{4}$ & $6.66 \times 10^{3}$ & $2.00 \times 10^{4}$ & $1.33 \times 10^{4}$ & $*$ & $8.33 \times 10^{3}$ \\
FOC-7 & $5.50 \times 10^{4}$ & $2.00 \times 10^{4}$ & $1.83 \times 10^{4}$ & $1.16 \times 10^{4}$ & $1.00 \times 10^{4}$ & $*$ & $5.00 \times 10^{3}$ \\
FOC-8 & $7.50 \times 10^{4}$ & $6.66 \times 10^{3}$ & $2.33 \times 10^{4}$ & $3.66 \times 10^{4}$ & $2.00 \times 10^{4}$ & $*$ & $2.66 \mathrm{x} 10^{4}$ \\
FOC-9 & $5.83 \times 10^{4}$ & $5.16 \times 10^{4}$ & $8.33 \times 10^{3}$ & $5.00 \times 10^{3}$ & $2.33 \times 10^{4}$ & $*$ & $3.33 \times 10^{3}$ \\
\hline
\end{tabular}

* No sporulation 
Table.7: Effect of culture media on production of macro conidia ofnine Fusarium oxysporumf. sp. ciceri isolates

\begin{tabular}{c|c|c|c|c|c|c|c}
\hline \multirow{2}{*}{ Is olates } & \multicolumn{7}{c}{ Production of macro conidia $\left(\mathbf{m l}^{-1}\right)$ on different media } \\
\cline { 2 - 8 } & PDA & CDA & MDA & CMA & OMA & WA & V8 JA \\
\hline FOC-1 & $3.27 \times 10^{5}$ & $4.38 \times 10^{4}$ & $2.44 \times 10^{4}$ & $5.55 \times 10^{3}$ & $3.94 \times 10^{4}$ & $*$ & $1.11 \times 10^{3}$ \\
FOC-2 & $9.07 \times 10^{4}$ & $4.50 \times 10^{4}$ & $3.50 \times 10^{4}$ & $3.33 \times 10^{3}$ & $3.77 \times 10^{4}$ & $*$ & $6.66 \times 10^{3}$ \\
FOC-3 & $1.75 \times 10^{5}$ & $1.02 \times 10^{4}$ & $4.46 \times 10^{3}$ & $1.49 \times 10^{3}$ & $4.96 \times 10^{3}$ & $*$ & $1.08 \times 10^{3}$ \\
FOC-4 & $1.58 \times 10^{5}$ & $1.50 \times 10^{5}$ & $1.16 \times 10^{4}$ & $1.66 \times 10^{3}$ & $2.66 \times 10^{4}$ & $*$ & $5.00 \times 10^{3}$ \\
FOC-5 & $9.00 \times 10^{4}$ & $5.00 \times 10^{3}$ & $*$ & $*$ & $8.33 \times 10^{3}$ & $*$ & $1.66 \times 10^{3}$ \\
FOC-6 & $5.00 \times 10^{4}$ & $5.00 \times 10^{4}$ & $*$ & $8.33 \times 10^{3}$ & $*$ & $*$ & $3.33 \times 10^{3}$ \\
FOC-7 & $3.33 \times 10^{3}$ & $5.00 \times 10^{4}$ & $5.33 \times 10^{4}$ & $1.66 \times 10^{3}$ & $2.00 \times 10^{4}$ & $*$ & $3.33 \times 10^{3}$ \\
FOC-8 & $8.33 \times 10^{3}$ & $*$ & $*$ & $6.66 \times 10^{3}$ & $1.00 \times 10^{4}$ & $*$ & $6.66 \times 10^{3}$ \\
FOC-9 & $1.06 \times 10^{5}$ & $1.55 \times 10^{5}$ & $6.16 \times 10^{4}$ & $1.66 \times 10^{3}$ & $7.50 \times 10^{4}$ & $*$ & $3.33 \times 10^{3}$ \\
\hline
\end{tabular}

* No sporulation

\section{Pathogenic variability}

In the present study it was observed that Fusarium wilt infected seedlings collapse and lies flat on the ground surface retaining their dull green color. Adult plants showed typical wilt symptoms of drooping of petioles, rachis and leaflets. The roots of the wilted plants did not show any external rotting but when split open vertically, dark brown discoloration of internal xylem was observed. According to these observations it was confirmed that $F$. oxysporum f. sp. ciceri is pathogenic to chickpea, which has also been supported by the findings of Nene (1980), who after making detailed symptomatolgical studies observed diagnostic symptoms of wilt at seedling stage (3-5 weeks after sowing). The present study indicates that wilt incidence at $30 \mathrm{DAI}$ and $60 \mathrm{DAI}$ varied from $0 \%$ to $13.33 \%$, at 45 DAI it was $6.67 \%$ to $53.33 \%$ whereas at 60
DAI it ranged from $13.33 \%$ to $86.67 \%$ (Table 8). The most virulent isolates were Foc-1 (86.67\% wilt incidence), Foc-7 (73.33\%) and Foc-8 (73.33\%) while, the least virulent isolate was Foc-6 (13.33\% wilt incidence). The remaining isolates showed intermediate response of variation in virulence. Ahmad (2010) noted that the pathogenic variability of 27 isolates against differential chickpea cultivars, the most virulence isolates was observed Foc-2 (AZRI, Bahawalpur), whereas, the least virulence was Foc-4 (Chakwal). Shehabu et al., (2008) studied 24 isolates for wilt resistance on 10 chickpea lines and eight improved varieties and found F13, F20 and F22 most virulent isolate. Haware et al., (1992) also found pathogenic diversity among chickpea wilt isolates.

Table.8: Wilt incidence and aggressiveness of nine Fusarium oxysporumf. sp. ciceri isolates on BARI Chola-1 at 30,45 and $60 \mathrm{DAI}$

\begin{tabular}{c|c|c|c|c}
\hline \multirow{2}{*}{ Isolates } & \multicolumn{2}{|c|}{ Wilt incidence (\%) at different days after inoculation (DAI) } & \multirow{2}{*}{ Aggressiveness } \\
\cline { 2 - 4 } & 30 DAI & $\mathbf{4 5}$ DAI & 60 DAI & HV \\
\hline FOC-1 & 13.33 & 53.33 & 86.67 & MV \\
FOC-2 & 0.00 & 13.33 & 40.00 & LV \\
FOC-3 & 6.67 & 13.33 & 20.00 & LV \\
FOC-4 & 0.00 & 13.33 & 20.00 & MV \\
FOC-5 & 13.33 & 40.00 & 46.67 & LV \\
FOC-6 & 0.00 & 6.67 & 13.33 & V \\
FOC-7 & 6.67 & 53.33 & 73.33 & V \\
FOC-8 & 6.67 & 53.33 & 73.33 & LV \\
FOC-9 & 0.00 & 13.33 & 20.00 & - \\
Control & 0.00 & 0.00 & 0.00 & \\
\hline
\end{tabular}

\section{REFERENCES}

[1] Ahmed, A. U. (1996). Variation of twenty seven isolates of Bipolaris sorokiniana from wheat. MS Thesis, Institute of Postgraduate Studies in Agriculture (IPSA) Salna, Gazipur, Bangladesh.
[2] Ahmad, M. A. (2010). Variability in Fusarium oxysporum f. sp. ciceris for chickpea wilt resistance in Pakistan. Ph.D Thesis. Quaid-i-Azam University, Islamabad, Pakistan.

[3] Barhate, B. G.; Dake, G. N.; Game, B. C. and Padule, D. N. (2006). Variability for virulence in $F$. 
oxysporum f. sp. ciceri causing wilt of chickpea. Legume Res. 29 (4): 308 - 310.

[4] Chaudhary, S. K. (1971). Studies of the Physiology of the Fusarium oxysporum f. udum (Butler) Snyder and Hansen (Causal Organism of Wilt of Cajanus cajan (Linn.) Millsp) Ph.D. Thesis, Deptt. of Bot. Ranchi University Ranchi, p. 297.

[5] Chauhan, S. K. (1962). Physiologic variation in $F$. orthoceras App. Wr. Var. ciceris causing wilt of gram. Proc. Natn. Acad. Sci. Sec. B. 22:78-84.

[6] Chauhan, S. K. (1963). Influence of different soils temperatures on the incidence of Fusarium wilt of gram (C. arietinum L.) Proc. Indian. Acad. Sci. 8, 33:552-554.

[7] Desai, S.; Nene, N. L. and Ramachandra Reddy, A. G. (1994). Races of Fusarium oxysporum causing wilt in chickpea. Indian Journal of Mycology and Plant Pathology 24: 120 - 127.

[8] Dubey S. C.; Singh, S. R. and Singh, B. (2010). Morphological and pathogenic variability of Indian isolates of Fusarium oxysporum f. sp. ciceris causing chickpea wilt. Archives of Phytopathology and Plant Protection 43(2): 174 - 190.

[9] FAO (2008). Food and Agriculture Organization Yearbook Production. Rome, Italy: 46: 105-115.

[10] Farooq, S.; Iqbal, S.M. and Rauf, A. (2005). Physiological studies of Fusarium oxysporum f. sp. ciceri. Int. J. Agri. Biol. 7(2): 275-277.

[11] Haware, M. P.; Nene, Y. L. and Rajeshware, R. (1978). Eradication of Fusarium oxysporum f. sp. ciceri transmitted in chickpea seed. Phytopathology 68: $1364-7$

[12] Haware, M. P.; Nene, Y. L.; Pundir, R. P. S. and Narayana, J. (1992). Screening of world chickpea germplasm for resistance to Fusarium wilt. Field Crops Res. 30: 147- 154.

[13] Imran Khan, H. S.; Saifulla M.; Mahesh, S. B. and Pallavi, M. S. (2011). Effect of different media and environmental conditions on the growth of Fusarium oxysporum f. sp. ciceri causing Fusarium wilt of chickpea. pp 67-78.

[14] Jamaria, S. L. (1972). Nutritional requirement of Fusarium oxysporum f. $\mathrm{sp}$. niveum. Indian Phytopathology 25:29-32.

[15] Khare, M. N.; Agarwal, S. C.; Dhyra O. D. and Kushwaha, L. S. (1975). Variability in the growth of light strains of Fusarium oxysporum f. sp. lentis as different solid media. Indian Phytopathology 28: 126-128.

[16] Khilare, V. C. and Rafi Ahmed (2012). Effect of different media, $\mathrm{pH}$ and temperature on the growth of Fusarium oxysporum f. sp. ciceri causing chickpea wilt. Int. J. of Advance Biological Research 2(1): 99-102.

[17] Mina, U. and Dubey, S. C. (2010). Effect of environmental variables on development of Fusarium wilt in chickpea (Cicer arietinum) cultivars. Indian J. Agric. Sci. 80(3):231-234.

[18] Nene, Y. L. and Haware, M. P. (1980). Screening chickpea for resistance to wilt. Pl. Dis. 64: 379-380.

[19] Nene, Y. L.; Haware, M. P. and Reddy, M. V. (1981). Chickpea diseases: resistance screening techniques. Information Bulletin No. 10, Int. Crop Res. Inst. for the Semi Arid Tropics, Patancheru. 110.

[20] Nene, Y. L.; Shiela, V. K. and Sharma, S. B. (1984). World list of chickpea (Cicer arietinum L.) and pigeonpea (Cajanus cajan) pathogens. ICRISAT. Pulse Pathology Programme report, 32:23 pp.

[21] Pande, S.; Galloway, Gaur, P.M.; Siddique, K. H. M.; Tripathi, H. S.; Taylor, P.; MacLeod, M. W. J.; Basadrai, A. K.; Bakr, M. A.; Joshi, S.; Kishore, K. G.; Isenegger, D.A.; Narayana, J. and Sharma, M. (2006). Botrytis gray mold of chickpea: a review of biology, epidemiology and disease management. Australian J. Agril. Res. 57: 1137-1150.

[22] Prasad, A.; Chaudhary, R. S. and Chaudhary, S. K. (1992). Effect of different $\mathrm{pH}$ levels on growth and sporulation of Fusarium moniliforme $V$. subglutinans $\mathrm{Wr}$. and $\mathrm{Rg}$., the causal organism of wilt of maize. Bio. J. 4( 1 and 2): 75-78.

[23] Saxena, M. C. and Singh, K. B. (1987). The chickpea published by C.A.B. Int. ICARDA. pp 250-252.

[24] Saxena, M. C. (1990). Problems and potential of chickpea production in the nineties. p. 13-27. In H. A. van Rheenen and M. C. Saxena (ed.) Chickpea in the nineties: Proceedings of the Second International Workshop on Chickpea Improvement. 4-8 Dec. (1989). ICRI- SAT, Patancheru, India. Chickpea diseases and their con RAPD markers. pp. 116.

[25] Shaikh, M. H. (1974). Studies on wilt of gram (Cicer arietinum L.) caused by $F$. oxysporum f. sp. ciceris in Marathwada region. M.Sc (Agri.) Thesis, Marathwada Krishividysapeeth, Parbhani, India. pp. 78-89.

[26] Sharma, K. D., Chen, W. and Muehlbauer, F. J. (2005). Genetics of chickpea resistance to five races of Fusarium wilt and a concise set of race differentials for $F$. oxysporum f. sp. ciceriss. Pl. Dis. 89:385-390.

[27] Shehabu, M.; Ahmed, S. and Sakhuja, P. K. (2008). Pathogenic variability in Ethiopian isolates of $F$. oxysporum f. sp. ciceris and reaction of chickpea 
improved varieties to the isolates. Int. J. Pest Management. 54(2):143-149.

[28] Singh, F.; Singh, N. and Gupta, P. K. (1986). Fusarium wilt of chickpea - Current status of the methods of study and measures to reduce crop losses. In: P. K. Gupta and J. Bahel (eds.) Genetics and Crop Improvement. Rastogi and Co., Meerut, pp. 133-148.

[29] Singh, K. B. and Reddy, M. V. (1991). Advances in disease resistance breeding in chickpea. Advances in Agron.45: 191-222.

[30] Swati, T. and Rajan, P. (2014). Effect of different $\mathrm{pH}$ on the growth and sporulation of Fusarium oxysporum: the causal organism of wilt disease of tomato. International Journal of Basic and Applied Biology (IJBAB) 2 (1): 103 - 106. 